\title{
THE EFFECTS OF AN INVASIVE ALIEN PLANT (CHROMOLAENA ODORATA) ON LARGE AFRICAN MAMMALS
}

\author{
Lihle Dumalisile', Michael J. Somers ${ }^{1,2}$ \\ ${ }^{1}$ Centre for Invasion Biology, Centre for Wildlife Management, University of Pretoria, South Africa \\ ${ }^{2}$ Mammal Research Institute, University of Pretoria, South Africa \\ e-mail:michael.somers@up.ac.za
}

Received: 29.08.2017

\begin{abstract}
Alien plants have invaded most ecosystem types (terrestrial, fresh water and marine) and are responsible for the loss of irreplaceable natural services on which humankind relies. They alter food quantity, quality and accessibility, and may result in declines in native species richness, which may ultimately result in extinction. For an effective management of invasive alien plants, it is important to understand the effects that such plants have on all levels of biodiversity. However, the effects that invasive alien plants, such as the Triffid weed (Chromolaena odorata), have on mammalian biodiversity, especially large mammalian species, are not well-known, although they play major ecological roles in areas such as nutrient cycling. Also, little is known about the recovery of the ecosystem following alien plant removal. This study investigated the effects of $C$. odorata invasion on large mammalian herbivores in Hluhluwe-iMfolozi Park and whether clearing of this plant helped in rehabilitating the habitat. We used track counts to estimate and compare species richness, diversity and abundance indices for large mammalian species between areas with differing $C$. odorata invasion durations ( $c a 2$ years, $c a 10$ years, $c a 20$ years), areas with differing clearing times ( $\mathrm{cl}<2$ years, $\mathrm{cl} 3-5$ years) and an area without any history of $C$. odorata invasion as a control. The results from this study show that large mammalian species utilised the uninvaded and the cleared areas more than the invaded areas. Species richness, abundance and diversity decreased with increasing invasion duration and cleared areas showed an increasing species richness and abundance. We conclude that this invasive alien plant modifies habitats and their removal does aid in the restoration of the ecosystem.
\end{abstract}

Key words: habitat disturbance, invasion duration, invasion ecology, restoration ecology, track counts

\section{Introduction}

Invasion by exotic species is the second largest threat after habitat destruction to global biodiversity (Schei, 1996). The impact of invasives can cause changes in ecosystem functioning (Vitousek, 1990) and a reduction in productivity for native species due to competitive interactions with the invader (Gould \& Gorchov, 2000; Miller \& Gorchov, 2004). Declines in native species richness occur in a variety of communities following invasion (D'Antonio \& Vitousek, 1992). However, quantitative data showing direct effects of invasives are rare, with predictions of extinctions linked to invasives often based on anecdotes, speculation and limited observation (Gurevitch \& Padilla, 2004).

Triffid weed, Chromolaena odorata (L.) R.M. King \& H. Rob. (Asteraceae), is native to the Neotropics and occurs in suitable areas below $1000 \mathrm{~m}$ (Zachariades \& Goodall, 2002). The plant is allelopathic (Fitter, 2003) and is one of the worst weeds in the southern African subregion (Goodall \& Erasmus, 1996). In KwaZulu-Natal province, South Africa, it has invaded nearly all conservation areas, and in Hluhluwe-iMfolozi Park (HiP) where the current study has been conducted, it poses a threat to the natural vegetation (Macdonald, 1983; Te Beest et al., 2017). There has been some success in its clearing in the HiP (Dew et al., 2017).

Alien species may effect various impacts on an ecosystem, from genetic impacts, impacts affecting individual organisms, impacts affecting populations, impacts affecting community structure and impacts affecting ecosystem processes (Parker et al., 1999; see Davis, 2009 for a review). These studies usually investigate the effects of alien invasions on invertebrates (e.g. Samways \& Taylor, 2004; Mgobozi et al., 2008) or on the vegetation (e.g. Te Beest et al., 2015) but seldom on mammals. This is despite large mammals having major ecological roles in ecosystems via nutrient cycling (Holland \& Detling, 1990; McNaughton et al., 1997) and in determination of vegetation structure and composition (Augustine \& McNaughton, 1998), which ultimately affect the abundance and diversity of most other taxa (Milchunas et al., 1998).

There is little documented information to show whether the ecosystem recovers after the removal of 
invasive alien species. Rozen-Rechels et al. (2017), using transect counts in HiP from 2004 and 2014, showed that the ungulates in the HiP do respond negatively to $C$. odorata, with grazers been more affected than browsers. Here we take a different approach to see what the long-term changes are in response to the clearing of $C$. odorata.

\section{Material and Methods}

HiP lies between latitudes $28^{\circ} 00^{\prime}$ to $28^{\circ}$ $26^{\prime} \mathrm{S}$ and longitudes $31^{\circ} 43^{\prime}$ to $32^{\circ} 09^{\prime} \mathrm{E}$ and is approximately $960 \mathrm{~km}^{2}$ in size (Howison, 2017) (Fig. 1). Using historical maps of the distribution of C. odorata in the park (provided by Ezemvelo KZN Wildlife), six treatments with differing $C$. odorata invasion durations and differing clearing times were selected. These treatments included one that had recently been invaded ( $\mathrm{ca} 2$ years); two that had been invaded for a longer period ( $c a 10$ years and $c a 20$ years); a treatment that had recently been cleared (cl $<2$ years); a treatment that had been cleared for a longer period ( $\mathrm{cl} 3-5$ years); and finally, as a control, a treatment without any history of $C$. odorata invasion. The treatments were located in the North East part of the park, where $C$. odorata invasion was the highest (Rozen-Rechels et al., 2017). All plots were in a section dominated by white Stinkwood trees (Celtis africana Burm.f.) and were very similar in vegetation composition, but differing in $C$. odorata invasion duration and clearing times.
We used tracking plots to estimate large mammalian species richness and diversity and abundance. In each of the six treatments, tracking plots were created along tracks that showed evidence of mammalian utilisation. Tracking plots were replicated eight times in each treatment, totalling 48 plots for the study. Located approximately $100 \mathrm{~m}$ apart and in different stands of C. odorata, each plot was created by removing the vegetation in a space $3 \times 1 \mathrm{~m}$. The plots were raked and smoothed and fine soil, of the same type as in the vicinity, was added to provide a good tracking surface and to ensure that the animals could not visually distinguish the plots from their usual road track. Using a Global Positioning System unit, the position of each tracking plot was recorded. All tracking plots were examined for tracks at least twice a week from February to June 2006, making a total of 27 tracking days. This was at the end of the rainy season and therefore rain did not interfere with the results. At each tracking plot, the number of track sets left by each mammal species was recorded, after which the plots were raked and smoothed in preparation for the following observation (e.g. Wilkie \& Finn 1990; Engeman \& Allen 2000; Engeman \& Evangilista 2006). To avoid pseudo-replication, an attempt was made to determine whether track sets belonged to the same animal that may have wondered around the plot or to two different animals.

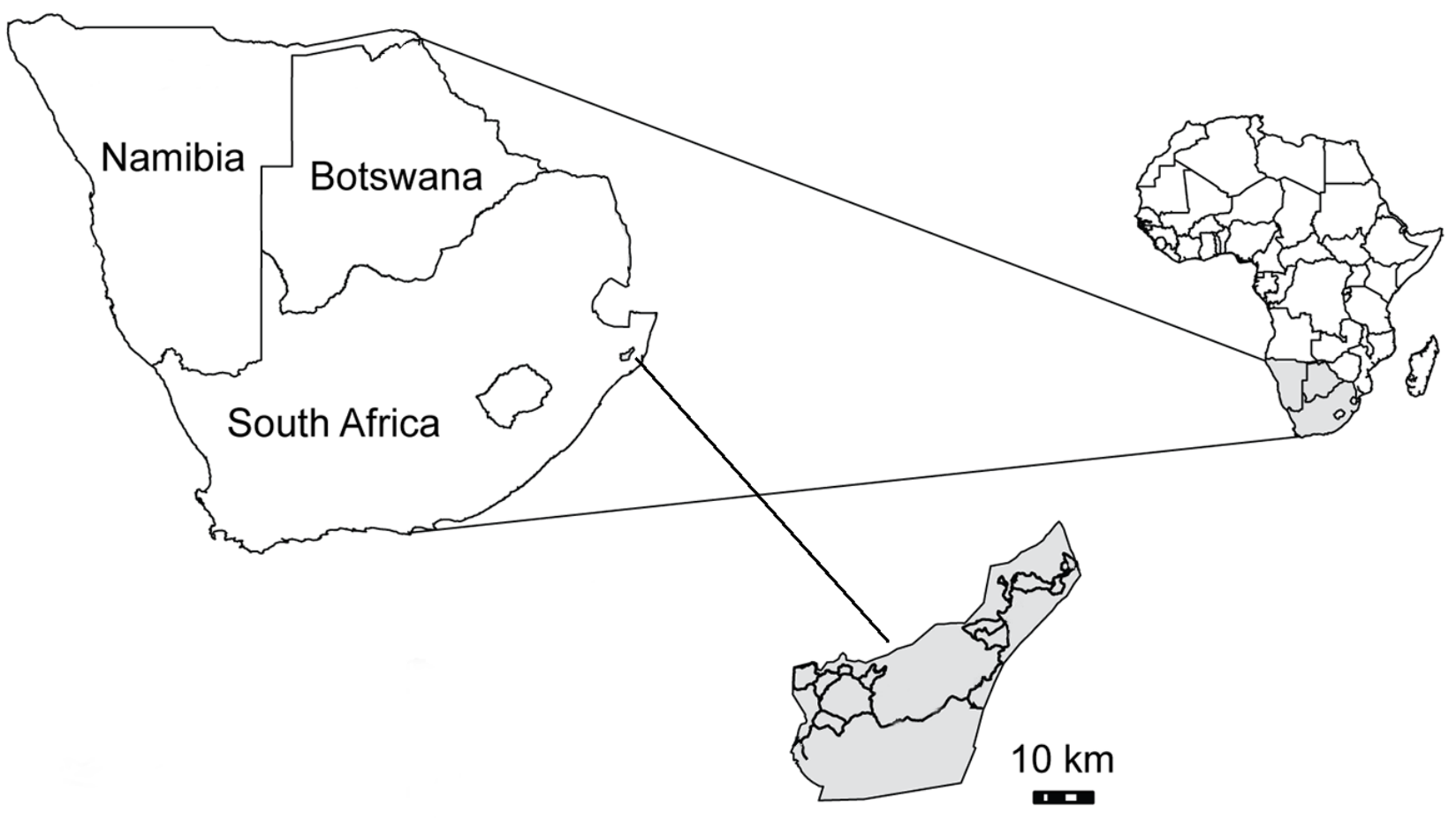

Hluhluwe-iMfolozi Park

Fig. 1. Geographical location of Hluhluwe-iMfolozi Park in South Africa. 
We calculated a relative index of species abundance for each species following Wilkie \& Finn (1990). A non-metric multidimensional scaling (nMDS) was constructed to graphically represent similarities or dissimilarities between treatments. The nMDS plots samples that are similar in their species composition are closer together and samples that differ in species composition are plotted further apart in a two-dimensional ordination space. An Analysis of Similarities (ANOSIM; $\mathrm{R})$ was used to test for significant differences in the animal species composition of the treatments. We calculated the Shannon and Simpson's diversity indices to further examine the differences in mammal species composition between the treatments. All these calculations were carried out using the PRIMER v5 software (PRIMER-E, Ltd., Plymouth, U.K.; Clarke \& Warwick, 2001). The Kruskal-Wallis test ANOVA $(\mathrm{H})$ was used to test for significant differences between the treatments using the diversity indices and the relative indices of abundances, at 5\% level of significance.

\section{Results}

We recorded 3469 tracks from 17 large mammal species. Table 1 shows the number of species recorded, the number of tracks recorded per species, the relative indices of abundance for each species, and the percentage of tracks per species, recorded per treatment. We found significant differences $(p>0.05)$ between the treatments with regard to diversity indices (Fig. 2), with the pairwise comparison showing that the $c a 10 \& 20$ yrs treatments were significantly different to the control (Table 2). The nMDS shows that there are differences in animal species composition between the selected treatments (Fig. 3). All six treatments were different in species composition (Global ANOSIM, $\mathrm{R}=0.946, p=0.001$; pairwise ANOSIM. Table 3). The pairwise ANOSIM test statistic R-values were all close to one (Table 3), suggesting that similarities between samples from one treatment are much less than any similarities between samples from other treatments. Based on this, the hypothesis of no differences is then rejected.

Table 1. The total number of tracks recorded, the total number of species recorded, the total percentage of tracks recorded per species in treatments with differing $C$. odorata invasion and clearing (cl) times and in the control area without any history of $C$. odorata invasion in Hluhluwe-iMfolozi Park. Relative indices of abundance for each species in each treatment are given in brackets

\begin{tabular}{|c|c|c|c|c|c|c|c|c|c|}
\hline Species & Common name & $\begin{array}{c}\text { No } \\
\text { invasion }\end{array}$ & $c a 2 \mathrm{yrs}$ & ca $10 \mathrm{yrs}$ & $c a 20 \mathrm{yrs}$ & $\mathrm{cl}<2 \mathrm{yrs}$ & cl 3-5yrs & Total & $\begin{array}{c}\text { Total, } \\
\%\end{array}$ \\
\hline $\begin{array}{l}\text { Aepyceros melampus Lichtenstein, } \\
1812\end{array}$ & Impala & $116(4.296)$ & $\begin{array}{c}110 \\
(4.074)\end{array}$ & $91(3.37)$ & $0(0)$ & $72(2.667)$ & $131(4.852)$ & 520 & 14.99 \\
\hline $\begin{array}{l}\text { Cephalophus natalensis A. Smith, } \\
1834\end{array}$ & Red duiker & $25(0.926)$ & $44(1.63)$ & $21(0.778)$ & $25(0.926)$ & $27(1)$ & $32(1.185)$ & 174 & 5.02 \\
\hline $\begin{array}{l}\text { Connochaetes taurinus Burchell, } \\
1823\end{array}$ & Blue wildebeest & $5(0.185)$ & $33(1.222)$ & $0(0)$ & $0(0)$ & $37(1.37)$ & $18(0.667)$ & 93 & 2.68 \\
\hline Ceratotherium simum Burchell, 1817 & White rhinoceros & $28(1.037)$ & $0(0)$ & $4(0.148)$ & $0(0)$ & $14(0.519)$ & $0(0)$ & 46 & 1.33 \\
\hline Crocuta crocuta (Erxleben, 1777) & Spotted hyaena & $0(0)$ & $0(0)$ & $2(0.074)$ & $0(0)$ & $0(0)$ & $0(0)$ & 2 & 0.06 \\
\hline Equus quagga Boddaert, 1785 & Plains zebra & $7(0.259)$ & $71(2.63)$ & $16(0.593)$ & $0(0)$ & $23(0.852)$ & $31(1.148)$ & 148 & 4.27 \\
\hline $\begin{array}{l}\text { Giraffa camelopardalis Linnaeus, } \\
1758\end{array}$ & Giraffe & $27(1)$ & $9(0.333)$ & $0(0)$ & $0(0)$ & $0(0)$ & $26(0.963)$ & 62 & 1.79 \\
\hline $\begin{array}{l}\text { Hippopotamus amphibius Linnaeus, } \\
1758\end{array}$ & Hippopotamus & $4(0.148)$ & $0(0)$ & $5(0.185)$ & $5(0.185)$ & $0(0)$ & $0(0)$ & 14 & 0.40 \\
\hline Kobus ellipsiprymnus Ogilbyi, 1833 & Waterbuck & $43(1.593)$ & $0(0)$ & $0(0)$ & $46(1.704)$ & $0(0)$ & $0(0)$ & 89 & 2.57 \\
\hline $\begin{array}{l}\text { Loxodonta africana Blumenbach, } \\
1797\end{array}$ & African elephant & $19(0.704)$ & $14(0.519)$ & $18(0.667)$ & $19(0.704)$ & $11(0.407)$ & $0(0)$ & 81 & 2.33 \\
\hline Panthera leo (Linnaeus, 1758) & Lion & $0(0)$ & $0(0)$ & $0(0)$ & $2(0.074)$ & $0(0)$ & $0(0)$ & 2 & 0.06 \\
\hline Papio hamadryas (Linnaeus, 1758) & Chacma baboon & $16(0.593)$ & $0(0)$ & $26(0.963)$ & $0(0)$ & $0(0)$ & $3(0.111)$ & 45 & 1.30 \\
\hline $\begin{array}{l}\text { Phacochoerus africanus Gmelin, } \\
1788\end{array}$ & Common warthog & $47(1.741)$ & $33(1.222)$ & $18(0.667)$ & $35(1.296)$ & $36(1.333)$ & $31(1.148)$ & 200 & 5.77 \\
\hline Redunca arundinum Boddaert, 1785 & Southern reedbuck & $13(0.481)$ & $5(0.185)$ & $17(0.63)$ & $10(0.37)$ & $0(0)$ & $9(0.333)$ & 54 & 1.56 \\
\hline Syncerus caffer Sparrman, 1779 & African buffalo & $76(2.185)$ & $0(0)$ & $0(0)$ & $0(0)$ & $\begin{array}{c}277 \\
(10.259)\end{array}$ & $33(1.222)$ & 386 & 11.13 \\
\hline $\begin{array}{l}\text { Tragelaphus angasii G.F. Angas, } \\
1849\end{array}$ & Nyala & $247(9.148)$ & $\begin{array}{c}244 \\
(9.037)\end{array}$ & $\begin{array}{c}269 \\
(9.963)\end{array}$ & $\begin{array}{c}223 \\
(8.259)\end{array}$ & $169(6.259)$ & $\begin{array}{c}319 \\
(11.815)\end{array}$ & 1471 & 42.40 \\
\hline $\begin{array}{l}\text { Tragelaphus strepsiceros P. Pallas, } \\
1766\end{array}$ & Greater kudu & $18(0.667)$ & $32(1.185)$ & $0(0)$ & $0(0)$ & $0(0)$ & $32(1.185)$ & 82 & 2.36 \\
\hline Total no. of tracks & & 691 & 595 & 487 & 365 & 666 & 665 & 3469 & 100 \\
\hline Total no. of species & & 15 & 10 & 11 & 8 & 9 & 11 & & \\
\hline
\end{tabular}


Table 2. Multiple Comparisons $P$ values (2-tailed) of Simpson and Shannon diversity indices for the different treatments with differing $C$. odorata invasion and clearing durations. Significant values $(P<0.05)$ are indicated in bold.

\begin{tabular}{|l|c|c|c|c|c|c|}
\hline & Control & $c \boldsymbol{c}$ 2yrs & $\boldsymbol{c a}$ 10yrs & $\boldsymbol{c a} \mathbf{2 0 y r s}$ & cl < 2yrs & cl 3-5yrs \\
\hline Simpson & & & & & & \\
\hline Control & & 1.0000 & $\mathbf{0 . 0 0 4 6}$ & $\mathbf{0 . 0 0 0 3}$ & 1.0000 & 0.3840 \\
\hline$c a$ 2yrs & 1.0000 & & 0.0606 & $\mathbf{0 . 0 0 6 5}$ & 1.0000 & 1.0000 \\
\hline$c a$ 10yrs & $\mathbf{0 . 0 0 4 6}$ & 0.0606 & & 1.0000 & 0.6825 & 1.0000 \\
\hline$c a$ 20yrs & $\mathbf{0 . 0 0 0 3}$ & $\mathbf{0 . 0 0 6 5}$ & 1.0000 & & 0.1233 & 0.6540 \\
\hline cl $<2$ yrs & 1.0000 & 1.0000 & 0.6825 & 0.1233 & & 1.0000 \\
\hline cl 3-5yrs & 0.3840 & 1.0000 & 1.0000 & 0.6540 & 1.0000 & \\
\hline Shannon & & & & & & \\
\hline Control & & 1.0000 & $\mathbf{0 . 0 0 1 7}$ & $\mathbf{0 . 0 0 0 1}$ & 0.2898 & 0.3039 \\
\hline$c a$ 2yrs & 1.0000 & & 0.2507 & $\mathbf{0 . 0 1 8 4}$ & 1.0000 & 1.0000 \\
\hline$c a 10 \mathrm{yrs}$ & $\mathbf{0 . 0 0 1 7}$ & 0.2507 & & 1.0000 & 1.0000 & 1.0000 \\
\hline$c a$ 20yrs & $\mathbf{0 . 0 0 0 1}$ & $\mathbf{0 . 0 1 8 4}$ & 1.0000 & & 0.2762 & 0.2632 \\
\hline $\mathrm{cl}<2 \mathrm{yrs}$ & 0.2898 & 1.0000 & 1.0000 & 0.2762 & & 1.0000 \\
\hline $\mathrm{cl} 3-5 \mathrm{yrs}$ & 0.3039 & 1.0000 & 1.0000 & 0.2632 & 1.0000 & \\
\hline
\end{tabular}

Table 3. ANOSIM results showing significant differences in large mammal composition in areas with differing $C$. odorata invasion and clearing $(\mathrm{cl})$ times and in the control area without any history of $C$. odorata invasion in HluhluweiMfolozi Park. Global R $=0.946 ; P=0.001$.

\begin{tabular}{|c|c|c|}
\hline Pairwise groups & Statistic (R) & $\begin{array}{l}\text { Level of significance } \\
\qquad(P)\end{array}$ \\
\hline control, ca 2yrs & 0.994 & 0.001 \\
\hline control, ca 10yrs & 0.935 & 0.001 \\
\hline control, ca 20yrs & 0.997 & 0.001 \\
\hline control, $\mathrm{cl}<2 \mathrm{yrs}$ & 1 & 0.001 \\
\hline control, cl 3-5yrs & 0.938 & 0.001 \\
\hline ca $2 \mathrm{yrs}$, ca $10 \mathrm{yrs}$ & 0.876 & 0.001 \\
\hline ca $2 \mathrm{yrs}$, ca $20 \mathrm{yrs}$ & 0.999 & 0.001 \\
\hline ca $2 \mathrm{yrs}, \mathrm{cl}<2 \mathrm{yrs}$ & 0.965 & 0.001 \\
\hline ca $2 \mathrm{yrs}, \mathrm{cl} 3-5 \mathrm{yrs}$ & 0.529 & 0.001 \\
\hline ca $10 \mathrm{yrs}$, ca $20 \mathrm{yrs}$ & 0.989 & 0.001 \\
\hline$c a 10 \mathrm{yrs}, \mathrm{cl}<2 \mathrm{yrs}$ & 0.993 & 0.001 \\
\hline ca 10yrs, cl 3-5yrs & 0.947 & 0.002 \\
\hline ca $20 \mathrm{yrs}, \mathrm{cl}<2 \mathrm{yrs}$ & 1 & 0.001 \\
\hline ca 20yrs, cl 3-5yrs & 1 & 0.001 \\
\hline $\mathrm{cl}<2 \mathrm{yrs}, \mathrm{cl} 3-5 \mathrm{yrs}$ & 0.999 & 0.001 \\
\hline
\end{tabular}

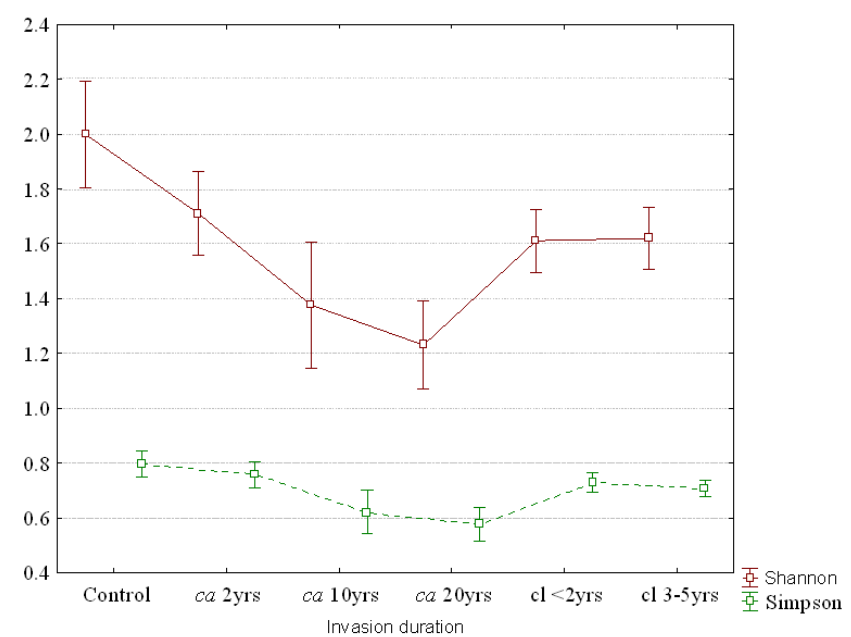

Fig. 2. Mean diversity ( $\pm 95 \%$ confidence limits) of mammals from areas with differing $C$. odorata invasion durations, differing $C$. odorata clearing $(\mathrm{cl})$ times, and in the control area without any history of $C$. odorata invasion in HluhluweiMfolozi Park, South Africa.

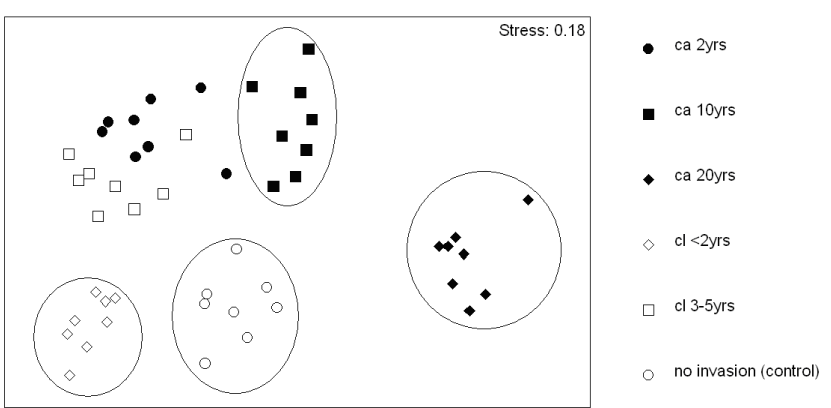

Fig. 3. nMDS showing large mammal assemblages in areas with differing $C$. odorata invasion durations, differing $C$. odorata clearing (cl) times, and in the control area without any history of $C$. odorata invasion in HluhluweiMfolozi Park, South Africa. 


\section{Discussion}

Chromolaena odorata is a dense, sometimes impenetrable bush, and our data suggest that this has a negative effect on large mammal communities. Although in a limited area within HiP we observed that mammalian species richness and diversity were highest in the control area after which it decreased with increasing $C$. odorata invasion duration, with the area that had been invaded for the longest time ( $c a 20$ years) displaying the lowest number of species. This suggests that the longer this invasive plant is left to establish itself, the less attractive the habitat becomes to many large mammals. These findings are supported by a multitude of studies which have found invasive plants to have a negative influence on native organisms (although mostly plants) and pose a threat to diversity (Richardson et al., 1994; Pyšek \& Pyšek, 1995; Cole \& Landres, 1996; Rozen-Rechels et al., 2017).

Although the treatments had the same vegetation types, they differed in species composition, which is attributed to the presence of $C$. odorata. The nMDS shows that the ca 20 yrs treatment displays the most different species composition in comparison to the others. This highlights the long-term impact of $C$. odorata. The abundances of some species (Table 1) are similar in invaded and un-invaded treatments, suggesting indifference in the use of these areas, or that these ungulates are perhaps using the thick $C$. odorata for shelter from predators. However, the absence of buffalo Syncerus caffer tracks in the invaded treatments suggests that, although they could provide shelter, these areas were not suitable habitat for other purposes. Buffalos are unselective bulk grazers (Sinclair, 1977), but they have been found to adjust their selection of grass species and feeding localities in relation to seasonal changes which change the quantity and quality of food (Macandza et al., 2004). It is assumed that they were using alternative and more suitable habitats. Our data on buffalos corroborate Rozen-Rechels et al. (2017) who, using transect sampling, showed grazers to be more affected than browsers. Lion (Panthera leo) and spotted hyaena (Crocuta crocuta) tracks were recorded only in densely invaded treatments ( $c a 10$ years and $c a 20$ years), which could be attributed to the lion's selecting areas where prey would be easier to catch (Hopcraft et al., 2005).

Our results suggest that $C$. odorata invasions change the habitat for use by large mammals by outcompeting native plant species either through their allelopathic characteristics (Zachariades \& Goodall, 2002; Fitter 2003), or by shading, or by competition for moisture or nutrients. Although diversity improves with the clearing of the plant, the species composition remains different to preinvasion state. This is concerning, as it appears, that the habitat may remain changed for a long time after clearing. Chromolaena odorata has also been found to have adverse effects on some of the high-profile mammalian species in South Africa, such as the Nile crocodile Crocodylus niloticus Laurenti, 1768 in the GSLWP (Leslie \& Spotila, 2001) and possibly the black rhinoceros Diceros bicornis (Linnaeus, 1758) in HiP (Reid et al., 2007). In the same study area, Mgobozi et al. (2008) found the progressive invasion of $C$. odorata brings with it changes in spider abundance, assemblage patterns, diversity and estimated species richness. However, spider assemblages are restored after clearing. The same trend occurred with small mammals in the area (Dumalisile, 2007). We conclude that $C$. odorata invasions negatively affect large mammal species' habitat use. $C$. odorata has been well managed and controlled in HiP but remains widespread and thus there is a risk of reinvasion (Te Beest et al., 2017). Follow up clearance of invasive alien plants is essential to restore ecosystem functioning ( $\mathrm{Te}$ Beest et al., 2017). More studies on the effects of alien invasives on different levels of biodiversity are a necessity.

\section{References}

Augustine D.J., McNaughton S.J. 1998. Ungulate effects on the functional species composition of plant communities: herbivore selectivity and plant tolerance. Journal of Wildlife Management 62: 1165-1183.

Clarke K.R., Warwick R.M. 2001. Change in marine communities: an approach to statistical analysis and interpretation, 2nd ed. Plymouth: Primer-E, Ltd. $172 \mathrm{p}$.

Cole D.N., Landres P.B. 1996. Threats to wilderness ecosystems: impacts and research needs. Ecological Applications 6: 168-184.

D’Antonio C., Vitousek P.M. 1992. Biological invasions by exotic grasses, the grass/fire cycle, and global change. Annual Review of Ecology and Systematics 23: 63-87.

Davis M.A. 2009. Invasion biology. Oxford: Oxford University Press. 264 p.

Dew L.A., Rozen-Rechels D., le Roux E., Cromsigt J.P.G.M., te Beest M. 2017. Evaluating the efficacy of invasive plant control in response to ecological factors. South African Journal of Botany 109: 203-213. 
Engeman R.M., Allen L. 2000. Overview of a passive tracking index for monitoring wild canids and associated species. Integrated Pest Management Reviews 5: 197-203.

Engeman R.M., Evangilista P. 2006. Investigating the feasibility of a passive tracking index for monitoring wildlife in the Lower Omo Valley, Ethiopia. African Journal of Ecology 45: 184-188.

Fitter A. 2003. Making allelopathy respectable. Science 301: 1337-1338.

Goodall J.M., Erasmus D.J. 1996. Review of the status of the invasive alien weed, Chromolaena odorata, in South Africa. Agriculture, Ecosystems \& Environment 56: 151-164.

Gould A.M.A., Gorchov D.L. 2000. Effects of the exotic invasive shrub Lonicera maackii, Amur honeysuckle, on survival and fecundity of native forest annual herbs. American Midland Naturalist 144: 36-50.

Gurevitch J., Padilla D.K. 2004. Are invasive species a major cause of extinctions? Trends in Ecology and Evolution 19: 470-474.

Holland E.A., Detling J.K. 1990. Plant responses to herbivory and belowground nitrogen cycling. Ecology 71: 1040-1049.

Hopcraft J.G.C., Sinclair A.R.E., Packer C. 2005. Planning for success: Serengeti lions seek prey accessibility rather than abundance. Journal of Animal Ecology 74: 559-566.

Howison R.A., Olff H., Owen-Smith N., Cromsigt J.P.G.M., Archibald S. 2017. The abiotic template for the Hluhluwe-iMfolozi Park's landscape heterogeneity. In: J.P.G.M. Cromsigt, S. Archibald, N. Owen-Smith (Eds.): Conserving Africa's mega-diversity in the Anthropocene: The Hluhluwe-iMfolozi Park story. Cambridge: Cambridge University Press. P. 33-55.

Leslie A.J., Spotila J.R. 2001. Alien plant threatens Nile crocodile (Crocodylus niloticus) breeding in Lake St. Lucia, South Africa. Biological Conservation 98: 347-355.

Macandza V.A., Owen-Smith N., Cross P.C. 2004. Forage selection by African buffalo in late dry season in two landscapes. South African Journal of Wildlife Research 34: 113-121.

MacDonald I.A.W. 1983. Alien trees, shrubs and creepers invading indigenous vegetation in the Hluhluwe-Umfolozi Game Reserve Complex in Natal. Bothalia 14: 949-959.

McNaughton S.J., Banyikwa F.F., MacNaughton M.M. 1997. Promotion of the cycling of diet-enhancing nutrients by African grazers. Science 278: 1798-1800.

Milchunas D.G., Lauenroth W.K., Burke I.C. 1998. Livestock grazing: animal and plant biodiversity of short grass steppe and the relationship to ecosystem function. Oikos 83: 65-74.

Miller K.E., Gorchov D.L. 2004. The invasive shrub, Lonicera maackii, reduces growth and fecundity of perennial forest herbs. Oecologia 139: 359-375.
Parker I.M., Simberloff D., Lonsdale W.M., Goodell K., Wonham M., Kareiva P.M., Williamson M.H., Von Holle B., Moyle P.B., Byers J.E., Goldwasser L. 1999. Impact: toward a framework for understanding the ecological effects of invaders. Biological Invasions 1: 3-19.

Pyšek P., Pyšek A. 1995. Invasion by Heracleum mantegazzianum in different habitats in the Czech Republic. Journal of Vegetation Science 6: 711-718.

Reid C., Slotow R., Howison O., Balfour D. 2007. Habitat changes reduce the carrying capacity of HluhluweUmfolozi Park, South Africa, for critically endangered black rhinoceros Diceros birconis. Oryx 41: 247-254.

Richardson D.M., Williams P.A., Hobbs R.J. 1994. Pine invasions in the southern hemisphere: determinants of spread and invadability. Journal of Biogeography 21: 511-527.

Rozen-Rechels D., te Beest M., Dew L.A., le Roux E., Druce D.J., Cromsigt J.P.G.M. 2017. Contrasting impacts of an alien invasive shrub on mammalian savanna herbivores revealed on a landscape scale. Diversity \& Distribution 23: 656-666.

Samways M.J., Taylor S. 2004. Impacts of invasive alien plants on red-listed South African dragonflies (Odonata). South African Journal of Science 100: 78-80.

Schei P.J. 1996. Conclusions and recommendations from the UN/Norway conference on alien species. Science International 63: 32-36.

Sinclair A.R.E. 1977. The African Buffalo: a study of resource limitation of populations. Chicago: The University of Chicago Press. 355 p.

Te Beest M., Mpandza N.J., Olff H. 2015. Fire and simulated herbivory have antagonistic effects on resistance of savanna grasslands to alien shrub invasion. Journal of Vegetation Science 26: 114-122.

Te Beest M., Owen-Smith, N., Howison R.A., Dew, L.A., Mgobozi Poswa, M., Dumalisile L., Janse van Rensburg S., Terblanche C. 2017. Successful control of the invasive shrub Chromoaena odorata in HluhluweiMfolozi Park. In: J.P.G.M. Cromsigt, S. Archibald, N. Owen-Smith (Eds.): Conserving Africa's mega-diversity in the Anthropocene: The Hluhluwe-iMfolozi Park story. Cambridge: Cambridge University Press. P. 358-382.

Vitousek P.M. 1990. Biological invasions and ecosystem processes: towards an integration of population biology and ecosystem studies. Oikos 57: 7-13.

Wilkie D.S., Finn J.T. 1990. Slash-burn cultivation and mammal abundance in the Ituri forest, Zaire. Biotropica 22: 90-99.

Zachariades C., Goodall J.M. 2002. Distribution, impact and management of Chromolaena odorata in Southern Africa. In: R. Zachariades, R. Muniappan, L.W. Strathie (Eds.): Proceedings of the Fifth International Workshop on Biological Control and Management of Chromolaena odorata. Durban, South Africa. P. 34-39. 


\title{
ВОЗДЕЙСТВИЕ ИНВАЗИОННОГО ЧУЖЕЗЕМНОГО РАСТЕНИЯ (CHROMOLAENA ODORATA) НА КРУПНЫХ МЛЕКОПИТАЮЩИХ АФРИКИ
}

\author{
Л. Думалисиле', М. Дж. Сомерс ${ }^{1,2}$ \\ ${ }^{1}$ Центр биологии инвазий, Центр управления дикой природой, Университет Претории, Южная Африка \\ ${ }^{2}$ Институт изучения млекопитающих, Университет Претории, Южная Африка \\ e-mail:michael.somers@up.ac.za
}

\begin{abstract}
Чужеземные растения внедрились в большинство типов экосистем (наземные, пресноводные, морские). И они являются причиной утраты незаменимых природных ресурсов, в которых нуждается и человек. Они изменяют количество, качество и доступность пищевых ресурсов и могут привести к снижению богатства разнообразия местных видов, что в конечном итоге может привести к исчезновению последних. Для эффективного управления инвазивными чужеземными растениями важно понять, какие воздействия оказывают такие растения на всех уровнях биоразнообразия. Однако эффекты воздействия, которые инвазивные чужеродные растения, такие как хромолена душистая (Chromolaena odorata), оказывают на биоразнообразие млекопитающих, особенно крупные виды, не известны. Хотя эти животные играют важную экологическую роль в таких областях, как круговорот питательных веществ. Кроме того, мало известно о восстановлении экосистемы после удаления чужеземных растений. В настоящем исследовании изучалось влияние инвазий $C$. odorata на крупных травоядных млекопитающих в парке ХлухлувеИмфолози и выяснялось, помогает ли уничтожение этого растения в восстановлении среды обитания. Мы использовали метод учетов для оценки и сопоставления показателей богатства, разнообразия и численности видов крупных млекопитающих между районами с различной продолжительностью инвазии $C$. odorata (около 2 лет, около 10 лет, около 20 лет), районами с разным временем удаления растения (менее 2 лет, около 3-5 лет) и областью, где инвазия C. odorata не была зарегистрирована, в качестве контроля. Результаты исследования показали, что крупные виды млекопитающих использовали незанятые чужеземным растением и очищенные от него районы больше, чем районы, подвергшиеся инвазии. Видовое богатство, численность и разнообразие млекопитающих уменьшались с увеличением продолжительности инвазии, а для очищенных районах показано увеличение видового богатства и численности. Мы пришли к выводу, что это инвазионное чужеземное растение изменяет местообитания, а его удаление из местообитания помогает в восстановлении экосистемы.
\end{abstract}

Ключевые слова: инвазионная экология, нарушение местообитания, продолжительность инвазии, учеты, экология восстановления 